\title{
Педагогічні умови формування готовності майбутніх лікарів до міжкультурної взаємодії
}

\section{А. І. Левицька, Т. Ю. Осипова}

Південноукраїнський національний педагогічний університет імені К. Д. Ушинського

Corresponding author. E-mail: a-io@mail.ua, osipovatanya2009@gmail.com

Paper received 25.10.21; Accepted for publication 15.11.21.

\section{https://doi.org/10.31174/SEND-PP2021-259IX101-06}

\begin{abstract}
Анотація. У статті висвітлено сутність педагогічних умов, що сприятимуть формуванню готовності майбутніх лікарів до міжкультурної взаємодії у професійній діяльності. Подано авторське розуміння поняття «педагогічні умови». Розглянуто необхідність створення полікультурного середовища в закладах вищої медичної освіти для формування вмінь і навичок міжкультурної комунікації студентів-майбутніх лікарів під час їхнього навчання в медичному виші. Полікультурне середовище медичного 3ВО - це освітній процес, учасниками якого $є$ представники різних культур, спрямований на формування полікультурної особистості майбутніх лікарів, які відрізняються національними, релігійними і культурними цінностями, спроможні розуміти інші культури та толерантно ставитися до них, здатні позиціонувати свою країну в умовах міжкультурної взаємодії, залучає їх до світових культурних традицій, виховання в них поваги до інших народів, забезпечення рівноправного діалогу з представниками інших культур, що відбувається на тлі толерантності і доброзичливості, у процесі професійної підготовки. Створення полікультурного середовища в медичному 3ВО сприятиме обізнаності студентів щодо культурного розмаїття у, формуванню в них ціннісного ставлення до національних особливостей представників різних культур; розвитку позитивної мотивації до взаємодії. Створенню полікультурного середовища ЗВО сприятимуть введення навчального курсу «Основи формування готовності майбутніх лікарів до міжкультурної взаємодії», оформлення навчальних приміщень плакатами і висловами про толерантність, випуск стіннівок, радіопередач, які будуть знайомити студентів із культурно-національними особливостями різних країн тощо. Доведено, що значну роль у підготовці майбутніх лікарів до міжкультурної взаємодії у професійній діяльності відіграє спрямування освітнього процесу на поглиблення теоретичних знань $\mathrm{i}$ формування практичних умінь і навичок міжкультурної взаємодії засобами інтерактивних методів навчання. Сутність інтерактивного навчання полягає в тому, що освітній процес здійснюється за умов постійної й активної взаємодії всіх учасників, де всі суб'єкти є рівноправними партнерами. Таке навчання ефективно сприяє формуванню ціннісних орієнтацій, навичок $\mathrm{i}$ вмінь, створенню атмосфери співпраці. До інтерактивних методів навчання належать: інтерактивні лекції, аналіз конкретних професійних ситуацій (кейс-стаді), мозковий штурм, рольові і ділові ігри, дискусії, квести, веб-квести тощо, використання яких на навчальних заняттях сприятиме усвідомленню важливості міжкультурної взаємодії майбутніх лікарів. необхідності вдосконалення знань культурно-національних особливостей представників різних культур, вмотивовутиме студентів до досягнення успіху в міжкультурній взаємодії в подальшій професійній діяльності, розвиватиме толерантність, емпатію, комунікативні вміння і вміння емоційної саморегуляції. Установлено, що вагоме місце у професійній підготовці майбутніх лікарів до міжкультурної взаємодії посідає позааудиторна діяльність студентів. Позааудиторна робота розглядається як спеціально організовані й цілеспрямовані позааудиторні заняття та система пізнавальних і виховних заходів, метою яких $\epsilon$ поглиблення та розширення знань, отриманих в умовах навчального процесу, розвиток творчих здібностей, задоволення наукових інтересів, опрацювання різноманітних умінь і навичок майбутніх фахівців. Позааудиторна робота включає участь у наукових гуртках, наукових товариствах, виховних заходах, фестивалях, конкурсах, інтелектуальних іграх, спортивних змаганнях, що проводяться в позанавчальний час.
\end{abstract}

Ключові слова: міжкультурна взаємодія; майбутні лікарі; полікультурне середовище; інтерактивні методи навчання, поза аудиторна діяльність.

Вступ. Будь-яке педагогічне дослідження передбачає визначення педагогічних умов, які сприяють формуванню певного педагогічного явища, що $є$ предметом дослідження. більшість дослідників дотримується думки, що педагогічні умови є спеціально створеними обставинами, які сприяють досягненню поставленої дослідником мети певного дослідження.

Аналіз останніх публікацій. Зазначимо, що педагогічні умови професійної підготовки майбутніх лікарів до різних видів діяльності були предметом дисертаційних досліджень таких науковців, як: Н Авраменко (Підготовка майбутніх лікарів-іноземців до оволодіння професійною термінологією у медичних закладах вищої освіти), І. Гуменна (Підготовка майбутніх лікарів до професійної комунікації на засадах міждисциплінарної інтеграції), Д. Дюрба (Організація позааудиторної роботи студентів вищого медичного навчального закладу), Г. Стечак (Педагогічна підготовка майбутніх сімейних лікарів у медичному університеті), Н. Шигонська.(Підготовка студентів медичних спеціальностей до професійної взаємодії засобами моделювання комунікативних ситуацій), А. Щербакова (Формування полікультурної компетентності у студентів-медиків у навчально-виховному процесі вищого медичного навчального закладу). Натомість педагогічні умови формування готовності майбутніх лікарів до міжкультурної взаємодії не були предметом окремого дослідження.

Метою статті $\epsilon$ наукове обгрунтування педагогічних умов формування готовності майбутніх лікарів до міжкультурної взаємодії.

Результати й обговорення. Під педагогічними умовами формування готовності майбутніх лікарів до міжкультурної взаємодії будемо розуміти спеціально створені обставини, які є необхідними і достатніми i передбачають використання в освітньому процесі сукупності об'єктивних можливостей змісту, форм, методів, засобів навчання, спрямованих формування готовності майбутніх лікарів до міжкультурної взаємодії, набуття необхідних для цього теоретичних знань, практичних умінь i навичок, особистісних i професійних якостей. Такими педагогічними умовами 
виступають: створення полікультурного освітнього середовища в медичному закладі вищої освіти; спрямування освітнього процесу на формування вмінь міжкультурної взаємодії засобами інтерактивних методів навчання; залучення майбутніх лікарів до організації конструктивної міжкультурної взаємодії в позааудиторній діяльності.

Першою педагогічною умовою обрано «Створення полікультурного освітнього середовища в медичному закладі вищої освіти. Середовище визначається як сукупність природних умов, у яких відбувається життєдіяльність якого-небудь організму; заповнене просторово-наочне, природне і соціальне оточення людини; сукупність природних умов, у яких відбувається життєдіяльність якого-небудь організму[1].

Під полікультурним середовищем медичного ЗВО розумісмо освітній процес, учасниками якого $є$ представники різних культур і який спрямований на формування полікультурної особистості майбутніх лікарів, що відрізняються національним і релігійними культурними цінностями, спроможні розуміти інші культури та толерантно ставитися до них, здатні позиціонувати свою країну в умовах міжкультурної взаємодії, залучає їх до світових культурних традицій, виховання в них поваги до інших народів, забезпечення рівноправного діалогу з представниками інших культур, що відбувається на тлі толерантності і доброзичливості, у процесі професійної підготовки Створення полікультурного середовища медичного ЗВО сприятиме обізнаності студентів щодо культурного розмаїття у світі, формуванню в них ціннісного ставлення до національних особливостей представників різних культур; розвитку позитивної мотивації до взаємодії з ними [3, с. 11.]. Створенню такого середовища сприятимуть введення навчального курсу «Основи формування готовності майбутніх лікарів до міжкультурної взаємодії», оформлення навчальних приміщень плакатами і висловами про толерантність, випуск стіннівок, радіопередач, які будуть знайомити студентів із культурно-національними особливостями різних країн тощо.

Іншою педагогічною умовою вважаємо «Спрямування освітнього процесу на формування вмінь міжкультурної взасмодії засобами інтерактивних методів навчання». Сутність інтерактивного навчання полягає в тому, що освітній процес здійснюється за умов постійної й активної взаємодії всіх учасників, де всі суб'єкти є рівноправними партнерами. Таке навчання ефективно сприяє формуванню ціннісних орієнтацій, навичок і вмінь, створенню атмосфери співпраці, взаємодії [9, с. 19]. До інтерактивних методів навчання належать: інтерактивні лекції, аналіз конкретних професійних ситуацій (кейс-стаді), мозковий штурм, рольові і ділові ігри, дискусії, квести, вебквести тощо. Рогянемо деякі інтерактивні методи.

Інтерактивна лекція - заняття, на якому нові знання студент одержує через проблемність питання, завдання чи ситуації. При цьому процес пізнання студентів у діалоговій співпраці з викладачем максимально наближений до дослідницької діяльності. Зміст проблеми розкривається шляхом організації можливих варіантів іï розв'язання чи за допомогою аналізу традиційних i новітніх поглядів на проблему [6, c. 103-104].

Аналіз конкретних професійних ситуацій (кейсстади) - глибоке й детальне вивчення реальних чи штучно створених умов професійної діяльності, необхідне для того, щоб з'ясувати характерні особливості майбутнього фаху 8 , с. 125].

мозковий штурм, - метод, сутність якого полягає в пошуках відповідей студентів на проблему через посередництво висловлювань, усіх можливих ідей, що спадають на думку, здогадок, пропозицій [10. с. 59].

Дискусія - метод, що передбачає використання учасниками заняття таких методів, як переконання, правильні емоції, компромісні рішення, селективний відбір інформації, вибудовування розумних відносин між прихильниками різних позицій [13, с. 191].

Рольові ігри - відтворення конкретних дій однієї 3 ролей у професійно-педагогічній діяльності [15].

Ділові ігри -імітаційне моделювання реальних механізмів і процесів, засобом розвитку не лише професійних умінь і навичок, але і професійного творчого мислення, в ході якої студенти набувають здатності аналізувати специфічні ситуації і вирішувати для себе нові завдання [12, с.25]

Квести - заняття, що дозволяють_активізувати розумову діяльність шляхом створення спеціальних умов для виконання завдань, які потребують достатньої свідомості й зрілості студентів, [4].

Освтній веб-квест - це сайт в Інтернеті, 3 яким працюють студенти, виконуючи те чи те навчальне завдання. Розробляються веб-квести для максимальної інтеграції Інтернету в різні навчальні предмети на різних рівнях навчання [7]:

Ще однією педагогічною умовою вважаємо «Залучення майбутніх лікарів до організації конструктивної міжкультурної взаємодії в позааудиторній діяльності». Позааудиторна робота - це спеціально організовані й цілеспрямовані позааудиторні заняття, метою яких $є$ поглиблення та розширення знань, отриманих в умовах навчального процесу, формування творчих інтересів, різноманітних умінь і навичок [5].

До наукової позааудиторної роботи належать студентські наукові гуртки, наукові товариства студентів і молодих учених (форми наукової діяльності студентів, спрямовані на розширення їхнього наукового потенціалу й формування навичок науково-дослідної діяльності у вільний від навчання час або спеціально відведений час),

До виховної позааудиторної роботи належать відвідування культурних подій, що сприяють естетичному та національно-патріотичному вихованню майбутніх лікарів (виставки, екскурсії містами та музеями України, перегляд кінофільмів, походи до театрів тощо), волонтерська діяльність (добровольна діяльність, благодійність, підтримка найбільш знедолених категорій населення; забезпечення гідного існування громадян, які в силу об'єктивних обставин не здатні піклуватися про себе самостійно); проведення різноманітних інтелектуальних ігор, тренінгів, фестивалів, конкурсів, ярмарок, спортивних змагань тощо. Позааудиторна діяльність насампреред спрямована на задоволення інтересів студентів, розвиток їхніх творчих зді- 
бностей, при цьому вона впливає на поглиблення їхніх знань і вдосконалення умінь і навичок міжкультурної взаємодії [14].

Висновки. На підставі теоретичного аналізу порушеної проблеми ми дійшли висновку, що педагогічні умови формування готовності майбутніх лікарів до міжкультурної взаємодії є взаємопов'язаними і взає- мозумовленими. Упровадження визначених педагогічних умов в освітній процес закладів вищої медичної освіти сприятиме поглибленню знань студентів щодо культурного розмаїття у світі, формуванню в них ціннісного ставлення до національних особливостей представників різних культур; розвитку позитивної мотивації до взаємодії з ними.

\section{ЛІТЕРАТУРА}

1. Великий тлумачний словник сучасної української мови / Уклад. і гол. ред. В. П. Бусел. Київ : Ірпінь: ВТФ «Перун», 2005. $1728 \mathrm{c}$.

2. Дюрба Д. В. Організація позааудиторної роботи студентів вищого медичного навчального закладу. URL:http://repo.knmu.edu.ua/handle/123456789/22055

3. Логвіненко А.Ю. Підготовка майбутніх учителів іноземної мови до формування толерантності в учнів основної школи:и автореф. Дис.... Канд.. пед. наук : 13.00.04 Оде$\mathrm{ca}-2017.23 \mathrm{c}$.

4. Педагогічний словник / За ред. М. Д. Ярмаченка. Київ : Пед. Думка, 2001. 514 с.

5. Радченко А. Є. Професійна компетентність учителя. Харків : Вид. група «Основа», 2006.128 с.

6. Романцова Ю. В. Веб-квест как способ активизации учебной деятельности учащихся. URL: http://открытыйурок.рф/статьи/513088/.

7. Руденко В. М. Формування професійно-комунікативної компетентності майбутніх філологів засобами інтерактивних технологій : дис... канд. пед. наук : 13.00.04. Черка-

си, 2010. - 288 с,

8. Сиротенко Г. О. Сучасний урок : інтерактивні технології навчання. Харків : Видав. гр. «Основа», 2003. 80 с.

9. Скрипник М. Технології використання різних методів інтерактивного навчаннк // Ігри дорослих. Інтерактивні методи навчання. Київ : Ред. загальнопед. газ., 2005. 128 c.

10. Толковый словарь русского языка / С. И. Ожегов, Н. Ю. Шведова. Москва : Азбуковник, 1997. 944 с

11. Хруцкий Е. А. Организация проведения деловых игр. Москва : Просвещение, 1991. 320 с,

12. Шкільняк Л.І. Дискусія як метод інтерактивного навчання у вищій медичній школі. Вісник Вінницького національного медичного університету. 2015. № 1. Т. 19. С. 190 192.

13. Школа волонтерів: навчальний посібник / За заг.ред. Г.С.Скитьової .Київ: 2016. 166 с.

14. Щербань П. М. Навчально-педагогічні ігри у вищих навчальних закладах : навчальний посібник. Київ : Вища школа, 2004. 207 с.
1. Large explanatory dictionary of the modern Ukrainian language / Uklad. and goal. ed. VP Busel. Kyiv: Irpin: VTF "Perun", 2005. 1728 p.

2. Durba DV Organization of extracurricular activities of students of higher medical education. URL: http: //repo.knmu.edu.ua/handle/123456789/22055

3. Logvinenko A.Yu. Preparation of future teachers of a foreign language for the formation of tolerance in primary school students: and author's ref. Dis.... Cand .. ped. наук: 13.00.04 Одеса - 2017. $23 \mathrm{c}$.

4. Mishagina OD The use of the quest as a means of enhancing the learning activities of students. URL: http://osvita.ua/school/lessons_summary/edu_technology/347 30/

5. Pedagogical Dictionary / Ed. MD Yarmachenko. Kyiv: Ped. Dumka, 2001. 514 p.

6. Radchenko AE Professional competence of the teacher. Kharkiv: Ed. Osnova group, 2006.128 p.

7. Romantsova Yu. V. Web-quest as a way to intensify the learning activities of students. URL: http: //открытыйурок.рф/статьи/513088/.

8. Rudenko VM Formation of professional-communicative

\section{ENCES}

competence of future philologists by means of interactive technologies: dissertation. ped. Science: 13.00.04. Cherkasy, 2010. - 288 p.

9. Sirotenko GO Modern lesson: interactive learning technologies. Kharkiv: Published. gr. Osnova, 2003. 80 p.

10. Skrypnyk M. Technologies for using different methods of interactive learning // Games for adults. Interactive teaching methods. Kyiv: Ed. general ped. Gaz., 2005. 128 p.

11. Explanatory dictionary of the Russian language / SI Ozhegov, N. Yu. Shvedova. Moscow: Azbukovnik, 1997. $944 \mathrm{p}$

12. Khrutsky EA Organization of business games. Moscow: Enlightenment, 1991. 320 p.

13. Shkilnyak LI Discussion as a method of interactive learning in higher medical school. Bulletin of Vinnytsia National Medical University. 2015. № 1. T. 19. S. 190192.

14. School of volunteers: a textbook / Ed. GS Skityova. Kyiv: 2016. $166 \mathrm{p}$.

15. Shcherban PM Educational and pedagogical games in higher educational institutions: a textbook. Kyiv: Higher School, 2004. 207 p.

\section{Pedagogical conditions of formation of readiness of future doctors for intercultural interaction}

\section{A. I. Levitska, T. Y. Osipova}

The article highlights the essence of pedagogical conditions that will contribute to the formation of readiness of future doctors for intercultural interaction in professional activities. The author's understanding of the concept of "pedagogical conditions" is given. The necessity of creating a multicultural environment in institutions of higher medical education for the formation of skills and abilities of intercultural communication of students-future doctors during their studies at a medical university is considered. The multicultural environment of medical health care is an educational process involving representatives of different cultures, aimed at forming a multicultural personality of future doctors who differ in national, religious and cultural values, are able to understand other cultures and be tolerant, able to position their country in intercultural conditions. interaction, attracts them to world cultural traditions, fostering in them respect for other peoples, ensuring equal dialogue with representatives of other cultures, which takes place against the background of tolerance and friendliness, in the process of training. The creation of a multicultural environment in medical health care will promote students' awareness of cultural diversity, the formation of their values to the national characteristics of different cultures; development of positive motivation to interact. The creation of a multicultural environment will be facilitated by the introduction of the training course "Fundamentals of future doctors' readiness for intercultural interaction", design of educational premises with posters and statements about tolerance, issue of wall hangings, radio programs that will acquaint students with cultural 
and national features of different countries. It is proved that a significant role in preparing future doctors for intercultural interaction in professional activities is played by the direction of the educational process to deepen theoretical knowledge and the formation of practical skills and skills of intercultural interaction through interactive teaching methods. The essence of interactive learning is that the educational process is carried out under the conditions of constant and active interaction of all participants, where all subjects are equal partners. Such training effectively contributes to the formation of value orientations, skills and abilities, creating an atmosphere of cooperation. Interactive teaching methods include: interactive lectures, analysis of specific professional situations (case studies), brainstorming, role and business games, discussions, quests, web quests, etc., the use of which in training will help to understand the importance of intercultural interaction of future doctors. the need to improve knowledge of cultural and national characteristics of different cultures, will motivate students to succeed in intercultural interaction in further professional activities, will develop tolerance, empathy, communication skills and emotional self-regulation skills. It is established that an important place in the professional training of future doctors for intercultural interaction is occupied by extracurricular activities of students. Extracurricular activities are considered as specially organized and purposeful extracurricular activities and a system of cognitive and educational activities aimed at deepening and expanding knowledge gained in the educational process, development of creative abilities, satisfaction of scientific interests, development of various skills of future professionals. Extracurricular work includes participation in scientific circles, scientific societies, educational events, festivals, competitions, intellectual games, sports competitions held in extracurricular time.

Keywords: intercultural interaction; future doctors; multicultural environment; interactive teaching methods, extracurricular activities. 